\title{
Determination of dietary iron requirements by full expression of iron-containing cytochrome $c$ oxidase in the heart of broilers from 22 to $42 \mathrm{~d}$ of age
}

\author{
Xiudong Liao, Chunyan Ma, Lin Lu, Liyang Zhang and Xugang Luo* \\ State Key Laboratory of Animal Nutrition, Mineral Nutrition Research Division, Institute of Animal Science, Chinese Academy \\ of Agricultural Sciences, Beijing 100193, People's Republic of China
}

(Submitted 5 June 2017 - Final revision received 13 August 2017 - Accepted 16 August 2017 - First published online 26 September 2017)

\begin{abstract}
The present study was carried out to determine dietary Fe requirements for the full expression of Fe-containing enzyme in broilers chicks from 22 to $42 \mathrm{~d}$ of age. At $22 \mathrm{~d}$ of age, 288 Arbor Acres male chicks were randomly assigned to one of six treatments with six replicates and fed a basal maize-soyabean-meal diet (control, containing $47.0 \mathrm{mg} \mathrm{Fe} / \mathrm{kg}$ ) or the basal diet supplemented with 20, 40, 60, 80 or 100 mg Fe/kg from $\mathrm{FeSO}_{4} .7 \mathrm{H}_{2} \mathrm{O}$ for $21 \mathrm{~d}$. Regression analysis was performed to estimate the optimal dietary Fe level using quadratic models. Liver cytochrome c oxidase (COx), heart Cox and kidney succinate dehydrogenase mRNA levels as well as heart COX activity were affected $(P<0 \cdot 08)$ by dietary Fe level, and COX mRNA level and activity in heart of broilers increased quadratically $(P<0.03)$ as dietary Fe level increased. The estimates of dietary Fe requirements were 110 and $104 \mathrm{mg} / \mathrm{kg}$ for the full expression of Cox mRNA and for its activity in the heart of broilers, respectively. The results from this study indicate that COX mRNA level and activity in the heart are new and sensitive criteria to evaluate the dietary Fe requirements of broilers, and the dietary Fe requirements would be $104-110 \mathrm{mg} / \mathrm{kg}$ to support the full expression of COX in the heart of broiler chicks from 22 to $42 \mathrm{~d}$ of age, which are higher than the current National Research Council Fe requirement ( $80 \mathrm{mg} / \mathrm{kg})$ of broiler chicks from 1 to $21 \mathrm{~d}$ or 22 to $42 \mathrm{~d}$ of age.
\end{abstract}

Key words: Iron: Iron-containing enzymes: Gene expression: Requirements: Broilers

Fe is an essential trace element, and it is required for the function of numerous critical enzymes in many biological processes for humans and animals ${ }^{(1,2)}$. Therefore, it is crucial to provide an optimal Fe level in the diet to prevent clinical deficiencies or ensure that the animals reach their optimal growth. The Fe requirement of broilers from 1 to $21 \mathrm{~d}$ of age was recommended to be $80 \mathrm{mg} / \mathrm{kg}$ by the National Research Council (NRC) ${ }^{(3)}$, and only estimated values were given for broilers after 3 weeks of age. Moreover, it was based on the limited information of few early studies using purified or semi-purified diets, and the parameters selected were growth performance, $\mathrm{Hb}$ concentration or haematocrit, which might be not the most sensitive indices to reflect the metabolic and molecular basis for the requirements of Fe in broiler chicks ${ }^{(4-6)}$. In addition, the results from early studies might not be applicable to practical diets because of the absence of antinutritional factors like phytate and fibre, which could inhibit Fe absorption by binding Fe in the intestinal tract and, thus, decrease Fe bioavailability ${ }^{(7-9)}$. Therefore, it is necessary to look for more sensitive criteria to evaluate Fe requirements of broiler chicks fed a practical maize-soyabean-meal diet.

It seems that most physiological consequences of $\mathrm{Fe}$ deficiency are attributed to anaemia, which can be identified by
$\mathrm{Hb}$ concentration or haematocrit. However, many patients could also suffer from definite symptoms of Fe deficiency without showing anaemia ${ }^{(10,11)}$. Thus, it is difficult to characterise other manifestations that are not related to anaemia but that may be attributed to compromised metabolic functions, in which Fe serves either as a cofactor or as an integral part of a protein or enzyme molecule ${ }^{(12,13)}$. Fe is required for the function of numerous Fe-containing enzymes, such as succinate dehydrogenase (SDH), cytochrome $\mathrm{c}$ oxidase (COX) and catalase (CAT), which are intimately associated with energy generation or elimination of reactive oxygen species of the mitochondria in various tissues ${ }^{(14,15)}$. Further, it has been reported that the activity of SDH, COX and CAT could be affected by the dietary Fe levels in rats and pigs ${ }^{(16,17)}$. More recently, in our laboratory, Ma et al. ${ }^{(18)}$ reported that the expression of liver SDH, COX and CAT and heart SDH activity as well as liver $S d h$ and Cox and heart Cox mRNA levels were new and sensitive criteria to evaluate the dietary $\mathrm{Fe}$ requirements of broilers from 1 to $21 \mathrm{~d}$ of age, and $97-136 \mathrm{mg} \mathrm{Fe} / \mathrm{kg}$ was required to support their full expression in various tissues. However, dietary $\mathrm{Fe}$ requirements for full expression of the above Fe-containing enzymes in various tissues of broiler chicks from 22 to $42 \mathrm{~d}$ of age has not been investigated.

Abbreviations: CAT, catalase; COX, cytochrome c oxidase; NRC, National Research Council; SDH, succinate dehydrogenase; TIBC, total Fe-binding capacity. 
obtain ferric Fe, which could be reduced to the ferrous state by hydroxylamine. Subsequently, the divalent Fe reacted with bathophrenanthroline to form a coloured complex, which was measured at $520 \mathrm{~nm}$. Transferrin in the plasma was saturated with Fe ions, and the unbound Fe was removed using analytical reagent-grade magnesium carbonate adsorption, and subsequent centrifugation was performed to collect the supernatants that were used for TIBC assays at $520 \mathrm{~nm}$. Finally, transferrin saturation $(\mathrm{TS})$ was calculated as $(\mathrm{PI} / \mathrm{TIBC}) \times 100^{(21,22)}$. The liver, heart and kidney were homogenised in $10 \%(\mathrm{w} / \mathrm{v})$ ice-cold physiological saline, and then sonicated with an ultrasonic-wave cell grinder (JY92-11; Ningbo Xinzhi Bio-technology Co., Ltd) for $1 \mathrm{~min}$ ( $1 \mathrm{~s}$ with $2 \mathrm{~s}$ interval). The homogenates were centrifuged at $1500 \boldsymbol{g}$ for $15 \mathrm{~min}$ at $4^{\circ} \mathrm{C}$ and supernatants were collected to determine total protein contents as well as SDH, CAT and COX activities. Total protein contents were determined using a BCA protein assay kit (catalogue no. 23225; Pierce). The activities of SDH and CAT in the supernatants were determined spectrophotometrically at 600 and $405 \mathrm{~nm}$ using commercial assay kits (catalogue no. A022 and A007-1; Nanjing Jiancheng Bioengineering Institute) and expressed as $\mathrm{U} / \mathrm{mg}$ protein, respectively; the COX activity was measured spectrophotometrically at $550 \mathrm{~nm}$ by means of a reagent set (GMS10014.3.2; Genmed Scientifics Inc.) and expressed as $\mathrm{mU} / \mathrm{mg}$ protein ${ }^{(23-25)}$. All of the above procedures were carried out according to the manufacturers' instructions.

\section{RNA extraction, reverse transcription and real-time $P C R$}

Total RNA was isolated from the liver, heart, kidney and femur marrow using Trizol reagent (Invitrogen) according to the manufacture's instruction. The concentration of each isolated RNA sample was determined using a NanoDrop Spectrophotometer (ND-2000; Gene Company Ltd), and the integrity of the RNA was checked using denatured RNA electrophoresis. A total of $1 \mu \mathrm{g}$ of RNA was used to obtain complementary DNA by reverse transcription using the Super Script First-Strand Synthesis System (Invitrogen). Real-time PCR reactions were performed on an ABI 7500 real-time PCR system using SYBRGreen PCR Master Mix (Applied Biosystems). The primer sequences for $S d h$, Cat, Cox, Hb, $\beta$-actin and glyceraldehyde3-phosphate dehydrogenase $(G A P D H)$ are given in Table 2. The protocol for PCR was as follows: denaturation at $95^{\circ} \mathrm{C}$ for $10 \mathrm{~min}$ followed by forty cycles of $94^{\circ} \mathrm{C}$ for $15 \mathrm{~s}$ and $60^{\circ} \mathrm{C}$ for $1 \mathrm{~min}$. The $2^{-\Delta \Delta C_{T}}$ was used to calculate the mRNA level of each target gene ${ }^{(26)}$. The geometric mean of internal reference genes, $\beta$-actin and GAPDH, was used to normalise the expression level of the target gene. The run was performed in triplicate.

\section{Statistical analysis}

The effect of dietary Fe treatment was analysed by one-way ANOVA using the general linear model procedure of SAS (version 9.2; SAS Institute Inc.). Differences among means were tested using the least-significant difference method. The replicate cage of eight chicks for growth performance indices or four chicks for other indices served as the experimental unit. Orthogonal comparisons were applied for linear and quadratic responses of dependent variables to independent variables. Regression analysis of broken-line, quadratic and asymptotic models were performed, respectively, and the quadratic models were shown to have the best fits between responsive criteria and dietary Fe levels; therefore, these quadratic models were chosen to estimate the optimal dietary Fe levels (the maximum responses from quadratic models) for broiler chicks ${ }^{(18,27-29)}$. The level of statistical significance was set at $P<0 \cdot 10^{(30-32)}$.

\section{Results}

\section{Growth performance}

Dietary Fe level did not affect $(P>0.25)$ daily body weight gain, daily feed intake and feed:gain ratio of broilers during days 22-42 (data not shown).

\section{Blood parameters}

Dietary Fe level did not affect $(P>0.35)$ PI, TIBC, TS, Hb concentration and haematocrit of broilers at $42 \mathrm{~d}$ of age (Table 3 ).

Table 3. Effect of dietary iron level on blood iron status variables of broilers at $42 \mathrm{~d}$ of age

(Mean values with their pooled standard errors, $n 6$ )

\begin{tabular}{lccccc}
\hline $\begin{array}{l}\text { Added Fe } \\
(\mathrm{mg} / \mathrm{kg})\end{array}$ & $\begin{array}{c}\mathrm{Pl} \\
(\mu \mathrm{g} / \mathrm{ml})\end{array}$ & $\begin{array}{c}\text { TIBC } \\
(\mu \mathrm{g} / \mathrm{ml})\end{array}$ & $\begin{array}{c}\mathrm{TS} \\
(\%)\end{array}$ & $\begin{array}{c}\mathrm{Hb} \\
(\mathrm{g} / 100 \mathrm{ml})\end{array}$ & $\begin{array}{c}\text { Haematocrit } \\
(\%)\end{array}$ \\
\hline 0 & 1.16 & 4.29 & 28.4 & 9.8 & 28.4 \\
20 & 1.09 & 4.52 & 28.1 & 10.4 & 28.5 \\
40 & 1.33 & 4.60 & 27.9 & 10.2 & 28.2 \\
60 & 1.22 & 4.75 & 29.5 & 10.3 & 28.5 \\
80 & 1.38 & 4.87 & 29.3 & 10.8 & 29.7 \\
100 & 1.27 & 5.01 & 26.2 & 10.8 & 29.2 \\
Pooled SEM & 0.10 & 0.44 & 3.24 & 0.33 & 0.71 \\
$P$ & 0.38 & 0.88 & 0.95 & 0.36 & 0.65 \\
\hline
\end{tabular}

PI, plasma Fe; TIBC, total Fe-binding capacity; TS, transferrin saturation.

Table 2. Primers used for the target and reference genes

\begin{tabular}{|c|c|c|}
\hline Genes & Forward & Reverse \\
\hline Cat & 5'-TTGCTGGAGAATCTGGGTC-3' & 5'-CCTTCAAATGAGTCTGAGGGTT-3' \\
\hline Cox & 5'- GCAGG GTTTCCTCCAT-3' & 5'-GGTTGCGGTCGGTAAGT-3' \\
\hline$H b$ & 5'-АCССТGTCAACTTCAAACTCC-3' & 5'-TTGGCTGCTCGCTGTCG-3' \\
\hline$S d h$ & 5'-TACAAATCCATCGAGCCTTAC-3' & 5'-GCACTCATAGAGTCCGTCCA-3' \\
\hline$\beta$-Actin & 5'-ACCTGAGCGCAAGTACTCTGTCT-3' & 5'-CATCGTACTCCTGCTTGCTGAT-3' \\
\hline GAPDH & 5'-CTTTGGCATTGTGGAGGGTC-3' & 5'-ACGCTGGGATGATGTTCTGG-3' \\
\hline
\end{tabular}

Cat, catalase; Cox, cytochrome c oxidase; Sdh, succinate dehydrogenase; GAPDH, glyceraldehyde-3-phosphate dehydrogenase. 
Table 4. Effect of dietary iron level on tissue iron concentrations of broilers at $42 \mathrm{~d}$ of age (Mean values with their pooled standard errors, $n 6$ )

\begin{tabular}{|c|c|c|c|c|c|c|c|}
\hline $\begin{array}{l}\text { Added Fe } \\
(\mathrm{mg} / \mathrm{kg})\end{array}$ & $\begin{array}{l}\text { Liver Fe } \\
(\mu \mathrm{g} / \mathrm{g})^{\star}\end{array}$ & $\begin{array}{l}\text { Heart Fe } \\
(\mu \mathrm{g} / \mathrm{g})^{\star}\end{array}$ & $\begin{array}{c}\text { Kidney Fe } \\
(\mu \mathrm{g} / \mathrm{g})^{\star}\end{array}$ & $\begin{array}{c}\text { Pancreas Fe } \\
(\mu \mathrm{g} / \mathrm{g})^{*}\end{array}$ & $\begin{array}{l}\text { Spleen Fe } \\
(\mu \mathrm{g} / \mathrm{g})^{\star}\end{array}$ & $\begin{array}{l}\text { Breast muscle } \\
(\mu \mathrm{g} / \mathrm{g})^{*}\end{array}$ & $\begin{array}{c}\text { Tibia bone ash Fe } \\
(\mu \mathrm{g} / \mathrm{g})\end{array}$ \\
\hline 0 & $95 \cdot 3^{b, c}$ & $26 \cdot 3^{b}$ & $26 \cdot 0$ & $14 \cdot 2$ & $99 \cdot 7$ & $4 \cdot 45^{\mathrm{a}, \mathrm{b}}$ & 274 \\
\hline 20 & $91.5^{\mathrm{C}}$ & $31.6^{\mathrm{a}}$ & 28.4 & $13 \cdot 9$ & $108 \cdot 8$ & $5 \cdot 13^{\mathrm{a}}$ & 255 \\
\hline 40 & $104^{\mathrm{b}, \mathrm{c}}$ & $32 \cdot 1^{a}$ & $28 \cdot 4$ & 13.8 & $113 \cdot 7$ & $3.85^{b, c}$ & 258 \\
\hline 60 & $110^{a, b, c}$ & $31 \cdot 4^{\mathrm{a}}$ & $26 \cdot 6$ & 13.7 & $104 \cdot 0$ & $3.98^{b, c}$ & 270 \\
\hline 80 & $114^{\mathrm{a}, \mathrm{b}}$ & $33.5^{\mathrm{a}}$ & 27.9 & 13.6 & $109 \cdot 1$ & $3.33^{\mathrm{C}}$ & 271 \\
\hline 100 & $126^{a}$ & $34.1^{\mathrm{a}}$ & $30 \cdot 1$ & $15 \cdot 4$ & 107.7 & $3 \cdot 81^{b, c}$ & 295 \\
\hline $\begin{array}{l}\text { Pooled SEM } \\
P\end{array}$ & 7.58 & 1.53 & 1.99 & 0.59 & 4.48 & 0.35 & 13.3 \\
\hline Fe level & 0.049 & 0.0168 & 0.73 & 0.30 & 0.36 & 0.0193 & 0.38 \\
\hline Linear & 0.0017 & 0.0016 & - & - & - & 0.0068 & - \\
\hline Quadratic & 0.57 & 0.23 & - & - & - & 0.63 & - \\
\hline
\end{tabular}

a,b,c Mean values within a column with unlike superscript letters were significantly different $(P<0.07)$.

${ }^{*}$ Fresh-weight basis.

Table 5. Effect of dietary iron level on mRNA levels of tissue iron-containing enzymes of broilers at $42 \mathrm{~d}$ of age (Mean values with their pooled standard errors, $n 6$ )

\begin{tabular}{|c|c|c|c|c|c|c|c|c|c|c|}
\hline \multirow[b]{2}{*}{ Added Fe (mg/kg) } & \multicolumn{3}{|c|}{ Liver $(R Q)^{\star}$} & \multicolumn{3}{|c|}{ Heart $(R Q)^{\star}$} & \multicolumn{3}{|c|}{ Kidney $(\mathrm{RQ})^{*}$} & \multirow{2}{*}{$\frac{\text { Femur marrow }(\mathrm{RQ})^{\star}}{H b}$} \\
\hline & $S d h$ & Cat & Cox & $S d h$ & Cat & Cox & $S d h$ & Cat & Cox & \\
\hline 0 & 1.41 & 1.07 & $0.84^{b}$ & 0.95 & 1.09 & $0.73^{b}$ & $0.83^{c}$ & 0.76 & 0.89 & 0.90 \\
\hline 20 & 1.47 & 1.08 & $1 \cdot 61^{a}$ & 0.90 & 0.89 & $0.99^{a, b}$ & $0.95^{\mathrm{b}, \mathrm{c}}$ & 0.84 & $1 \cdot 12$ & 0.98 \\
\hline 40 & $1 \cdot 34$ & $1 \cdot 15$ & $1 \cdot 26^{a}$ & 0.87 & $1 \cdot 14$ & $1 \cdot 03^{a, b}$ & $0.82^{c}$ & 0.80 & 0.81 & 1.02 \\
\hline 60 & $1 \cdot 34$ & 1.40 & $1 \cdot 31^{\mathrm{a}}$ & 0.92 & 0.93 & $1 \cdot 24^{\mathrm{a}}$ & $0.98^{a, b}$ & 0.74 & 0.79 & $1 \cdot 27$ \\
\hline 80 & $1 \cdot 28$ & $1 \cdot 26$ & $1 \cdot 31^{\mathrm{a}}$ & 0.91 & 1.01 & $1 \cdot 20^{\mathrm{a}}$ & $0.91^{b, c}$ & 0.62 & 0.74 & $1 \cdot 32$ \\
\hline 100 & $1 \cdot 18$ & $1 \cdot 25$ & $1.38^{a}$ & 0.93 & 1.02 & $0.99^{a, b}$ & $1.08^{a}$ & 0.71 & 0.99 & $1 \cdot 34$ \\
\hline $\begin{array}{l}\text { Pooled SEM } \\
P\end{array}$ & $0 \cdot 15$ & $0 \cdot 13$ & 0.17 & 0.09 & 0.14 & 0.12 & 0.60 & 0.11 & 0.13 & $0 \cdot 16$ \\
\hline Fe level & 0.84 & 0.50 & 0.0713 & 0.99 & 0.83 & 0.0634 & 0.0078 & 0.73 & 0.28 & 0.28 \\
\hline Linear & - & - & 0.18 & - & - & 0.0412 & 0.004 & - & - & - \\
\hline Quadratic & - & - & 0.17 & - & - & 0.0200 & 0.30 & - & - & - \\
\hline
\end{tabular}

$\mathrm{RQ}$, relative quantities; Sdh, succinate dehydrogenase; Cat, catalase; Cox, cytochrome c oxidase; GAPDH, glyceraldehyde-3-phosphate dehydrogenase.

$\mathrm{a}, \mathrm{b}, \mathrm{c}$ Mean values within a column with unlike superscript letters were significantly different $(P<0.09)$.

* The mRNA levels were calculated as the RQ of the target gene mRNA to the geometric mean of $\beta$-actin $\mathrm{mRNA}$ and $G A P D H, \mathrm{RQ}=2^{-\triangle \Delta C_{T}}\left(C_{T}\right.$, threshold cycle).

\section{Iron concentrations}

The Fe concentrations in kidney, pancreas, spleen and tibia bone ash of broilers at $42 \mathrm{~d}$ of age were not affected $(P>0.29)$ by dietary Fe level (Table 4). However, Fe concentrations in liver, heart and breast muscle of broilers at $42 \mathrm{~d}$ of age were affected $(P<0.05)$ by the dietary $\mathrm{Fe}$ level, which increased linearly $(P<0.007)$ as dietary Fe level increased; therefore, none of these three tissues was suitable for assaying Fe requirement.

\section{mRNA levels}

Dietary Fe level did not affect $(P>0 \cdot 27) S d h$ and Cat mRNA levels in liver and heart, Cat and Cox mRNA levels in kidney and $H b$ mRNA level in femur marrow, but affected $(P<0 \cdot 08)$ Cox mRNA level in liver and heart as well as $S d b$ mRNA level in kidney of broilers at $42 \mathrm{~d}$ of age (Table 5). The heart Cox mRNA level increased quadratically $(P<0.03)$ as dietary Fe level increased, and reached a plateau at a supplementation of approximately $60-80 \mathrm{mg} \mathrm{Fe} / \mathrm{kg}$.

\section{Enzyme activity}

Dietary Fe level did not affect $(P>0 \cdot 15)$ the SDH, CAT and COX activity in liver, SDH and CAT activity in heart as well as SDH and CAT activity in kidney; however, COX activity in heart of broilers at $42 \mathrm{~d}$ of age was affected $(P<0 \cdot 0001)$ (Table 6$)$. The COX activity in the heart increased quadratically $(P<0.0001)$ as dietary Fe level increased, and reached the highest point at a supplementation of $60 \mathrm{mg} \mathrm{Fe} / \mathrm{kg}$.

\section{Dietary iron requirements}

Results of the dietary Fe requirements of broilers as estimated by the non-linear regression analysis are presented in Table 7. Based on fitted quadratic-curve models $(P<0.008)$ of COX mRNA level and activity in the heart, optimal dietary Fe levels were estimated to be $104-110 \mathrm{mg} / \mathrm{kg}$ for broiler chicks fed a maize-soyabean-meal diet from 22 to $42 \mathrm{~d}$ of age.

\section{Discussion}

It is difficult to characterise other manifestations that are not related to anaemia but that may be attributed to metabolic defects $^{(15)}$. Therefore, it is critically important to find sensitive indices to evaluate Fe nutritional status of animals. The present study demonstrates that heart COX mRNA level and activity are new and more sensitive criteria for evaluating Fe nutritional 
Table 6. Effect of dietary iron level on tissue iron-containing enzyme activity of broilers at $42 \mathrm{~d}$ of age (Mean values with their pooled standard errors, $n 6$ )

\begin{tabular}{|c|c|c|c|c|c|c|c|c|}
\hline \multirow[b]{2}{*}{$\begin{array}{l}\text { Added Fe } \\
(\mathrm{mg} / \mathrm{kg})\end{array}$} & \multicolumn{3}{|c|}{ Liver } & \multicolumn{3}{|c|}{ Heart } & \multicolumn{2}{|c|}{ Kidney } \\
\hline & $\begin{array}{l}\mathrm{SDH}(\mathrm{U} / \mathrm{mg} \\
\text { protein) }\end{array}$ & $\begin{array}{l}\mathrm{CAT}(\mathrm{U} / \mathrm{mg} \\
\text { protein) }\end{array}$ & $\begin{array}{l}\mathrm{COX}(\mathrm{mU} / \mathrm{mg} \\
\text { protein) }\end{array}$ & $\begin{array}{l}\mathrm{SDH}(\mathrm{U} / \mathrm{mg} \\
\text { protein) }\end{array}$ & $\begin{array}{c}\text { CAT (U/mg } \\
\text { protein) }\end{array}$ & $\begin{array}{l}\mathrm{COX}(\mathrm{mU} / \mathrm{mg} \\
\text { protein) }\end{array}$ & $\begin{array}{l}\mathrm{SDH}(\mathrm{U} / \mathrm{mg} \\
\text { protein) }\end{array}$ & $\begin{array}{l}\text { CAT (U/mg } \\
\text { protein) }\end{array}$ \\
\hline 0 & 7.89 & $17 \cdot 8$ & 45.5 & $10 \cdot 8$ & 1.77 & $4.02^{d}$ & $10 \cdot 9$ & $18 \cdot 3$ \\
\hline 20 & 8.39 & 18.5 & 47.8 & 11.9 & 1.78 & $5 \cdot 20^{\mathrm{C}}$ & $10 \cdot 5$ & $20 \cdot 3$ \\
\hline 40 & $10 \cdot 1$ & 18.5 & 48.4 & $12 \cdot 3$ & 1.71 & $5 \cdot 78^{\mathrm{b}}$ & 11.6 & 23.4 \\
\hline 60 & 8.81 & 18.2 & 52.1 & 13.4 & 1.62 & $7.06^{a}$ & 14.7 & 24.2 \\
\hline 80 & 8.48 & $20 \cdot 2$ & 47.8 & 14.8 & 1.73 & $5.59^{b}$ & 11.4 & 20.4 \\
\hline 100 & $9 \cdot 38$ & $17 \cdot 0$ & $47 \cdot 0$ & $13 \cdot 3$ & 1.57 & $4.99^{\mathrm{C}}$ & $10 \cdot 7$ & $20 \cdot 4$ \\
\hline $\begin{array}{l}\text { Pooled SEM } \\
P\end{array}$ & 0.81 & $2 \cdot 20$ & 0.22 & 1.08 & 0.13 & 0.14 & $1 \cdot 28$ & 2.8 \\
\hline Fe level & 0.48 & 0.95 & 0.44 & 0.17 & 0.84 & $<0.0001$ & 0.15 & 0.69 \\
\hline Linear & - & - & - & - & - & $<0.0001$ & - & - \\
\hline Quadratic & - & - & - & - & - & $<0.0001$ & - & - \\
\hline
\end{tabular}

$\mathrm{SDH}$, succinate dehydrogenase; CAT, catalase; COX, cytochrome c oxidase.

a,b,c,d Mean values within a column with unlike superscript letters were significantly different $(P<0.07)$.

Table 7. Dietary iron requirements of broilers from 22 to $42 \mathrm{~d}$ of age as estimated based on fitted quadratic-curve models

\begin{tabular}{lllll}
\hline Dependent variables & Regression equation* & $R^{2}$ & $P$ & Dietary Fe requirement (mg/kg) \\
\hline Heart Cox mRNA level & $Y=-0.2460+0.02601 X-0.0001178 X^{2}$ & 0.2833 & $<0.008$ & 110 \\
Heart COX activity & $Y=-1.8467+0.1581 X-0.0007612 X^{2}$ & 0.7508 & $<0.0001$ & 104 \\
\hline
\end{tabular}

${ }^{*} Y$ is the dependent variable and $X$ is the analysed Fe concentration in the basal diet plus supplemental Fe level (mg/kg).

status of broilers fed a maize-soyabean-meal diet from 22 to $42 \mathrm{~d}$ of age than growth, $\mathrm{Hb}$ concentration or haematocrit.

To our knowledge, very limited information concerning Fe requirement of broilers during days -42 is available so far, and only estimated value of $\mathrm{Fe}$ requirement for broilers after 3 weeks of age was given by the $\mathrm{NRC}^{(3)}$. Moreover, in these earlier studies, growth performance, $\mathrm{Hb}$ concentration and haematocrit were often used to assess Fe requirements in chicks fed purified or semi-purified diets, and the Fe requirements for broilers during days 1-21 (or days 1-29) were defined as $45-85 \mathrm{mg} / \mathrm{kg}^{(4,5,6,33-35)}$. On the other hand, Vahl et al. ${ }^{(36)}$ and Ma et al. ${ }^{(18)}$ reported that the Fe requirements in broilers fed a practical maize-soyabean-meal diet were 100 and $118 \mathrm{mg} / \mathrm{kg}$ for the optimum growth from 1 to 21 or 1 to $39 \mathrm{~d}$ of age, respectively. The Fe requirements in broilers fed the practical diets are higher than requirements for those fed purified or semi-purified diets, which might be due to the adverse effect of phytate and fibre on $\mathrm{Fe}$ absorption ${ }^{(7-9)}$. Nevertheless, the growth performance is always influenced by the type of diets or growth phase and, thus, it might not be a good index for assessing Fe requirements for broilers. Besides, many studies have demonstrated that haematological indices, such as $\mathrm{Hb}$ concentration or haematocrit, could reflect the Fe nutritional status or be a sensitive criteria for estimating the Fe requirement of broilers fed purified or semi-purified diets ${ }^{(4,36)}$. Ma et al. ${ }^{(37)}$ found that blood $\mathrm{Hb}$ concentration and haematocrit of chicks fed a casein-dextrose diet increased linearly as dietary Fe level increased; Davis et al. ${ }^{(4)}$ reported that the Fe requirements of chicks fed a soyabean protein-casein-gelatin diet were 78 and $77 \mathrm{mg} / \mathrm{kg}$ for $\mathrm{Hb}$ concentration and haematocrit, respectively. However, the present study showed that dietary Fe concentration had no effect on growth performance and blood Fe status parameters of broilers from 22 to $42 \mathrm{~d}$ of age, suggesting that $\mathrm{Hb}$ concentration and haematocrit were not sensitive criteria for estimating Fe requirement of broilers when a conventional maizesoyabean-meal diet was used.

Many studies showed that the Fe concentration in tissues increased as the dietary Fe level increased, and the change in Fe concentration in tissues could reflect the Fe status of animals: especially, the Fe concentration in liver ${ }^{(18,38,39)}$. In the present study, it was also found that Fe concentrations in the liver and heart increased as dietary Fe level increased, which was similar to findings from early studies ${ }^{(18)}$. However, Fe contents in these tissues did not reach a plateau with increasing dietary Fe levels, and a better linear response was observed, suggesting that these indices would be better used to evaluate the bioavailability of different Fe sources in broilers than to assess the threshold of adequacy.

The gene expression and activity of Fe-containing enzymes might be another type of new and more sensitive biomarkers for assessing Fe nutritional status of animals as, like all other essential trace elements, $\mathrm{Fe}$ is a component or a cofactor of numerous Fe-containing enzymes, and functions in the body mainly through Fe-containing enzymes, such as SDH, COX and $\mathrm{CAT}^{(13,16)}$. It was found that SDH and CAT activity in the liver of pigs $^{(17)}$ and broilers ${ }^{(18)}$ first increased, and then decreased when the added Fe levels increased from 0 to $120 \mathrm{mg} / \mathrm{kg}$ in the maize-soyabean basal diet, suggesting that liver SDH and CAT activity could sensitively reflect the $\mathrm{Fe}$ nutritional status of animals. However, the results from our current study showed that dietary Fe level did not affect the SDH and CAT activity in the heart, liver and kidney of broilers, which might be due to the different types of animals and growth phases studied or due 
to previous Fe accumulation in these tissues (the diet containing $127 \mathrm{mg} \mathrm{Fe} / \mathrm{kg}$ during days 1-21). In the present study, it was found that the COX mRNA level and activity in heart increased quadratically as dietary $\mathrm{Fe}$ level increased, and they were sensitive biomarkers to assess $\mathrm{Fe}$ status and $\mathrm{Fe}$ requirements for broilers fed a maize-soyabean-meal diet from 22 to $42 \mathrm{~d}$ of age. Our previous study also found that Cox mRNA level in the heart was a new and sensitive criterion for assessing the Fe requirements of broilers fed the maize-soyabean-meal diet from 1 to $21 \mathrm{~d}$ of age ${ }^{(18)}$. Moreover, a similar phenomenon was also reported in other studies. Siimes et al. ${ }^{(14)}$ reported that even the mildest degree of Fe-deficiency anaemia was also accompanied by depletion of cytochrome c; de Deungria et $a l^{(16)}$ found that supplemental Fe increased the COX activity in the brain of rats. The abovementioned results, together with those of the present study, demonstrated that COX expression was a sensitive criterion for estimating Fe nutritional status of animals. Therefore, in order to meet all metabolic Fe needs, the dietary Fe levels of $104-110 \mathrm{mg} / \mathrm{kg}$ would be recommended as the dietary Fe requirements for broilers. However, considering the effect of sex on dietary Fe requirements of broilers, a combined study (male and female) or separate study focusing on female broilers needs to be conducted in the future to justify the requirement of Fe during 22 to $42 \mathrm{~d}$ of age.

In conclusion, the results from the present study indicate that COX mRNA level and activity in the heart are new and sensitive criteria to evaluate the dietary Fe requirements of broilers, and the dietary $\mathrm{Fe}$ requirements are $104-110 \mathrm{mg} / \mathrm{kg}$ to support full expression of COX in the heart of broilers fed the maizesoyabean-meal diet from 22 to $42 \mathrm{~d}$ of age, which are higher than the dietary Fe requirement $(80 \mathrm{mg} / \mathrm{kg}$ ) of broiler chicks from 1 to $21 \mathrm{~d}$ or 22 to $42 \mathrm{~d}$ of age as recommended by the $\mathrm{NRC}^{(3)}$.

\section{Acknowledgements}

The authors would like to thank the personnel of these teams for their kind assistance.

The present study was supported by the Agricultural Science and Technology Innovation Program (ASTIP-IAS08), the China Agriculture Research System (project no. CARS-42), the Program of the National Natural Science Foundation of China (project no. 31672440), the Research Program of the Key Laboratory of Animal Nutrition (project no. 2004DA125184G1606) and the Program of Student Community of Professor Yang Sheng (project no. 2016A20010).

The authors' contributions are as follows: $\mathrm{X}$. Luo and X. Liao designed the experiment; X. Liao drafted the article; X. Luo and L. L. participated in writing and editing the article; C. M. conducted most of the experiments and analysed the data; L. Z. performed the Fe analysis; X. Luo had primary responsibility for the final content. All authors read and approved the final version of the article.

The authors have no financial or personal conflicts of interest to declare.

\section{References}

1. Strube YN, Beard JL \& Ross AC (2002) Iron deficiency and marginal vitamin A deficiency affect growth, hematological indices and the regulation of iron metabolism genes in rats. J Nutr 132, 3607-3615.
2. Wang W, Di X, D'Agostino RB Jr., et al. (2007) Excess capacity of the iron regulatory protein system. $J$ Biol Chem 282, 24650-24659.

3. National Research Council (1994) Nutrient Requirements of Poultry, 9th ed. Washington, DC: National Academies Press.

4. Davis PN, Norris LC \& Kratzer FH (1968) Iron utilization and metabolism in the chick. J Nutr 94, 407-417.

5. McNaughton JL \& Day EJ (1979) Effect of dietary Fe to $\mathrm{Cu}$ ratios on hematological and growth responses of broiler chickens. J Nutr 109, 559-564.

6. Southern LL \& Baker DH (1982) Iron status of the chick as affected by Eimeria acervulina infection and by variable iron ingestion. J Nutr 112, 2353-2362.

7. Widdowson EM \& Mccance RA (1942) Iron exchange of adults on white and brown bread diets. Lancet 239, 588-591.

8. Biehl RR, Emmert JL \& Baker DH (1997) Iron bioavailability in soybean meal as affected by supplemental phytase and 1 alpha-hydroxycholecalciferol. Poult Sci 76, 1424-1427.

9. Reinhold JG, Garcia JS \& Garzon P (1981) Binding of iron by fiber of wheat and maize. Am J Clin Nutr 34, 1384-1391.

10. Waldenström J (1938) Iron and epithelium. Some clinical observations. Acta Med Scand 95, 380-397.

11. Waldenström J (1946) The incidence of 'iron deficiency' (sideropenia) in some rural and urban populations. Acta Med Scand 170, Suppl., S252-S279.

12. Dallman PR, Beutler E \& Finch CA (1978) Effects of iron deficiency exclusive of anaemia. BrJ Haematol 40, 179-184.

13. Rao J \& Jagadeesan V (1996) Lipid peroxidation and activities of antioxidant enzymes in iron deficiency and effect of carcinogen feeding. Free Radic Biol Med 21, 103-108.

14. Siimes MA, Refino C \& Dallman PR (1980) Manifestation of iron deficiency at various levels of dietary iron intake. Am J Clin Nutr 33, 570-574.

15. Hagler L, Askew EW, Neville JR, et al. (1981) Influence of dietary iron deficiency on hemoglobin, myoglobin, their respective reductases, and skeletal muscle mitochondrial respiration. Am J Clin Nutr 34, 2169-2177.

16. de Deungria M, Rao R, Wobken JD, et al. (2000) Perinatal iron deficiency decreases cytochrome c oxidase (CytOx) activity in selected regions of neonatal rat brain. Pediatr Res $\mathbf{4 8}$, $169-176$.

17. Feng J, Ma WQ, Xu ZR, et al. (2009) The effect of iron glycine chelate on tissue mineral levels, fecal mineral concentration, and liver antioxidant enzyme activity in weanling pigs. Anim Feed Sci Tech 150, 106-113.

18. Ma XY, Liao XD, Lu L, et al. (2016) Determination of dietary iron requirements by full expression of ironcontaining enzymes in various tissues of broilers. J Nutr $\mathbf{1 4 6}$, 2267-2273.

19. Yang QM \& Diao YX (2003) The Handbook for Raising of Broilers. Beijing: China Agricultural University Press.

20. Huang YL, Lu L, Luo XG, et al. (2007) An optimal dietary zinc level of broiler chicks fed a corn-soybean meal diet. Poult Sci 86, 2582-2589.

21. Huebers HA, Eng MJ, Josephson BM, et al. (1987) Plasma iron and transferrin iron-binding capacity evaluated by colorimetric and immunoprecipitation methods. Clin Chem 33, 273-277.

22. International Committee for Standardization in Haematology (1978) The measurement of total and unsaturated iron-binding capacity in serum. Br J Haematol 38, 281-287.

23. Nulton-Persson AC \& Szweda LI (2001) Modulation of mitochondrial function by hydrogen peroxide. $\mathrm{J}$ Biol Chem 276, 23357-23361.

24. Zhang SS, Su HG, Zhou Y, et al. (2016) Effects of sustained cold and heat stress on energy intake, growth and mitochondrial function of broiler chickens. J Integr Agr 15, 2336-2342. 
25. Hou H, Li BF, Zhao X, et al. (2009) The effect of pacific cod (Gadus macrocephalus) skin gelatin polypeptides on UV radiation-induced skin photoaging in ICR mice. Food Chem 115, 945-950.

26. Livak KJ \& Schmittgen TD (2001) Analysis of relative gene expression data using real-time quantitative PCR and the 2(-Delta Delta C(T)) method. Methods 25, 402-408.

27. Corzo A, Dozier WA \& Kidd MT (2006) Dietary lysine needs of late-developing heavy broilers. Poult Sci $\mathbf{8 5}$, 457-461.

28. Robbins KR, Norton HW \& Baker DH (1979) Estimation of nutrient requirements from growth data. J Nutr 109, $1710-1714$.

29. Lu L, Chang B, Liao XD, et al. (2016) Use of molecular biomarkers to estimate manganese requirements for broiler chickens from 22 to $42 \mathrm{~d}$ of age. Br J Nutr 116, 1512-1518.

30. Li S, Luo X, Liu B, et al. (2004) Use of chemical characteristics to predict relative bioavailability of supplemental organic manganese sources for broilers. J Anim Sci 82, 2352-2363.

31. Luo XG, Li SF, Lu L, et al. (2007) Gene expression of manganese-containing superoxide dismutase as a biomarker of manganese bioavailability for manganese sources in broilers. Poult Sci 86, 888-894.
32. Liao XD, Li A, Lu L, et al. (2013) Optimal dietary zinc levels of broiler chicks fed a corn-soybean meal diet from 22 to 42 days of age. Anim Prod Sci 53, 388-394.

33. Waddell GD \& Sell LJ (1964) Effects of dietary calcium and phosphorus on the utilization of dietary iron by the chick. Poult Sci 43, 1249-1257.

34. Aoyagi S \& Baker DH (1995) Iron requirement of chicks fed a semipurified diet based on casein and soy protein concentrate. Poult Sci 74, 412-415.

35. Bao YM, Choct M, Iji PA, et al. (2007) Effect of organically complexed copper, iron, manganese, and zinc on broiler performance, mineral excretion, and accumulation in tissues. J Appl Poult Res 16, 448-455.

36. Vahl HA \& van 'T Klooster AT (1987) Dietary iron and broiler performance. Br Poult Sci 28, 567-576.

37. Ma XY, Liu SB, Lu L, et al. (2014) Relative bioavailability of iron proteinate for broilers fed a casein-dextrose diet. Poult Sci 93, 556-563.

38. Wensing T, Abdelrahim AI \& Schotman AJH (1986) Some aspects of extra iron supply in veal calf fattening. Vet Res Commun 10, 283-296.

39. Furugouri K (1972) Effect of elevated dietary levels of iron on iron store in liver, some blood constituents and phosphorus deficiency in young swine. J Anim Sci 34, 573-577. 